\title{
A Success Story Revisited: Base Funding for Horticultural Research
}

\author{
Clive W. Donoho, Jr. \\ Georgia A gricultural Experiment Stations, U niversity of Georgia, A thens, GA 30602
}

I was asked to discuss formula funding, but I have chosen to use the term base funding to represent both federal formula funding and state appropriations. Base funding represents the appropriated funds that come to every experiment station in the nation, and these funds have few, if any, strings or earmarking attached.

Our president, Dr. George Martin, published a presidential editorial in the Sept. 1990 ASHS Newsletter entitled, "Formula Funding" that nearly preempted this presentation because many of the arguments for formula funding made in his article also reflect my strong belief and philosophy for formula funding. The only major exception I take with his excellent editorial is in what I will call "administration bashing." Our agricultural research system and our horticultural society does need good administrative leadership with strong hands-on research experiences and backgrounds. An indictment of research administrators as the sole problem with our research funding, research planning, and research management is not only unjustified, in my view, but it may encourage a widespread attitude of anti-administration that may deter many potentially good leaders from seriously considering administrative roles. Our horticultural society and colleges of agriculture need to cultivate, encourage, and train outstanding leaders for administrative positions.

Nearly every agricultural dean, experiment station director, or horticulture department head is strongly committed and supportive of base funding to his or her agricultural research programs. If that statement is true, then why do we have the current dichotomy between base funding and competitive grants? For example, why have there been more increases in competitive funding than base funding in the U.S. Dept. of Agriculture (USDA) in recent years? It has occurred because many bureaucrats and legislators (especially federal congressmen) prefer the competitive grant system over the block formula appropriation of research funds. Congressmen like it for several reasons. First, the peer review process has been sold as a process to fund the best science and scientists. Incidentally, support for the peer review process for publications and grants was largely initiated and encouraged by scientists. In addition, legislators can announce the competitive grant awards to their state clients. The 
bottom line is that competitive grants are politically more acceptable to congressmen than formula, block funding to states or to Land Grant Universities. This is a legislative, political reality that is not easily overcome when we try to make the case for funding agricultural research through the formula process.

Batting averages also become an important part of the perception and attitude of research administrators. Our system has been pushing federal formula funds and state appropriations for many years, but increases in federal formula funds over the years have not been as dramatic as many of us would like, even though those funds still form the base of our support for agriculture research at most of our universities. When you go to the Congress year after year with strong justifiable requests for additional formula funds and you get, at most, only cost-of-doing-business increases, you begin to look at all possible sources of funding for the research program.

Most agricultural administrators continue to voice strong support for base funding, but they also encourage scientists to be aware of outside grant funding that will support their research programs. It is not a matter of placing one in preference over the other. It is a matter of trying to take advantage of all sources of funds to support a planned research effort. I view competitive grant funds as an opportunity for scientists to strengthen their base-funded research programs.

Base funding of agricultural research started nationally with the passage of the Hatch Act in 1887. It provided a formula level of funding to every state's experiment stations and required a matching amount from the state. This strengthened the concept and need for state appropriations for agricultural research programs. Today, most of our states are providing far more base funding to our agricultural research programs than the federal formula provides. But the federal formula funds are the glue that holds together our state experiment station research system in a major national agricultural research effort that essentially is the envy of the world.

Base funding is absolutely essential if we are going to approach solving many of the difficult problems facing agriculture in the years ahead. There are indeed areas of important horticultural research that do not currently lend themselves to competitive grant funding, and if we are going to do that essential research, we simply must make the administrative decision to continue to do it with base funding.

There are many advantages to funding horticultural and other agricultural research through base funding (Martin, 1990). An internationally known plant physiologist and horticulturist has stated that "None of us could contest the high value and importance of competitive grants and peer review. There is a danger, however, that we can overload the research system with peer reviewing when block funding of agricultural research can offer distinctive and timely advantage," (Leopold, 1989). Dr. Don Holt, director of the Illinois Agricultural Experiment Station, recently has written a long thesis on formula funding entitled, "Capturing the Vision: the Case for Formula Funds." Director Holt (1989) makes a strong case for federal formula funding in his 16-page paper, and concludes by stating "Formula funds address extremely important needs to support a research infrastructure, provide continuity to programs, and tap the great reservoir of scientists and administrative creativity that extends on the front lines of the U.S. agricultural research system." While Director Holt's paper only addresses the federal formula funds system, everything he writes also would be appropriate for the agricultural research funding we receive from our respective states.

Sometimes there is a misconception on the part of agricultural scientists about how much base funding is supporting their individual research programs. Let me give you a real life, personal example.

Recently, one of our experiment station scientists, a full professor, completed a rather large outside grant proposal. The guidelines called for the identification of a total amount of funding that would be available from the University to support the research effort if the grant were approved. The figure he reported was $\$ 4,800$. He simply did not recognize the amount of base funding that was being provided to him and his program as being direct research support. His $\$ 65,000$ salary, his $\$ 26,000$ technician, and his $\$ 11,000$ graduate student all were part of his formula research support. In addition, there was a $\$ 25,000$ piece of equipment that had been purchased for his program six months earlier, and he had no charge access to a state vehicle, station computers, and statistical counseling, the library, photographic laboratory, laboratory space, managed field plots, and all publication costs. These were all part of his direct formula or base-funded research support. The only research support he related to as support for his research program from the experiment station and his department was the $\$ 4,800$ his department head had given him that year for supplies and travel.

Federal and state appropriations (base funding) for agricultural research has been and still is the current base or cornerstone of all our colleges of agriculture research programs. Every one of us needs to work hard at supporting the continuation and expansion of this support if we are to have the organizational structure and means of attracting alternative means of research funding.

All sources of research funding are important. Base funding is absolutely essential, but we also need a good, competitive grant program specifically designed for agricultural research. The new USDA Competitive Grant Program represented by "the National Research Initiative" will provide such a program. Competitive grants should add to or be supplemental to our base research programs. I encourage scientists and department heads to first plan their research programs carefully, and then search for all possible sources of funds to support that plan. The scientist working with the department head must judge the specific research priorities and the research course of action.

We at the Univ. of Georgia try hard to provide a base level of support from appropriated funds to all scientists, but we also ask them to accept some of the responsibility for generating the extra level of funding that could move their programs from just being good to being outstanding.

In conclusion, I would like to offer researchers 11 specific suggestions that might be helpful for increasing total funding support.

1) Continue to be accountable for the research support you get. That includes your salary. Be productive, publish your results, and let people know what you are doing. Be a leader in your field. Dramatic research accomplishments will do more to sustain and expand base or formula funding than anything you or any of us can do.

2) Evaluate your research program and your research interests. Where does it fit? Who will benefit most? Is there an organization, industry, or federal agency that would have an interest in the research objectives you plan to pursue?

3) If you prepare funding proposals, do so in areas where you know there is money for research support in your area of interest. Shotgunning proposals to a large array of granting agencies usually doesn't work very well. Also, chasing dollars just for dollars is unjustified.

4) If you do prepare a grant proposal, closely follow the agency guidelines. Many research grants are never seriously considered because the writer simply did not follow the guidelines for preparing the proposal.

5) Don 't overlook the possibility of funding from other city, county, or state agencies. Also, state commodity groups often are a very good source for supplemental funding for your state and Hatch projects.

6) Get advice and help. Talk with scientists who have been successful in generating funding for their programs. Talk with your department head about your ideas and make sure those ideas for supplemental funding conform with your research goals and those of your department.

7) Don't get discouraged. Even the most successful faculty seldom get more than one proposal approved out of every three or four submitted.

8) Keep those scientific publications coming. Nothing will support your funding requests for additional formula funds or for outside grants funds more than having a sound publication record. The research data in your filing cabinets are of no help. Get them published.

9) Look for opportunities for cooperative research with scientists 
in other departments. There may be a well-funded research program next door that has research objectives similar to yours, and it may need your talent.

10) Let your critical funding needs be known through your department head. Maybe your department head or experiment station director won't be able to help you today, but tomorrow may be different. Most department heads and directors I know are especially receptive to helping new faculty get started in their research programs.

11) Be ready and be prepared. Funding opportunities often arrive with very short notice or deadlines. Don't wait until you are asked if you need additional funding or until you have received the grant announcement on your desk. Have those equipment requisitions ready or research proposals outlined before you receive the notices.

One of the main purposes of a good administrator is to assist and help. Administrators and experiment station directors spend a lot of time and effort in promoting and justifying agricultural research to assure that we continue to get the base or hard money support; however, administrators cannot do this job alone. The success and outside recognition of individual scientist's research programs will be the one most essential ingredient for selling the need to continue and expand base funding for horticultural research in the years ahead.

\section{Literature Cited}

Holt, D. 1989. Capturing the vision: the care for formula funds. ARI Proceedings, p. 33-49.

Leopold, C. 1989. A critique of methods for funding research. ARI Proceedings, p. 57-58.

Martin, G. 1990. Formula Funding. Reflections, ASHS Nwsl. vol. 6 no. 9. 